\title{
ASSOCIATION OF METABOLIC SYNDROME WITH DEVELOPMENT OF PRE-ECLAMPSIA AMONG PREGNANT WOMEN
}

\author{
Wafaa H. A. Zahran(1); Hala I. Awad Allah ${ }^{(2)}$ \\ and Alaa El Din A. A. El Guindy ${ }^{(3)}$
}

1) Post grad. Student, Institute of Environmental studies \&Research, Ain Shams University 2) Department of Environmental Medical Sciences Institute of Environmental studies \&Research, Ain Shams University 3) Obstetrics and Gynecology Department, Faculty of Medicine, Ain Shams University

\begin{abstract}
Background: Preeclampsia is a complicated disorder in pregnancy which occurs after 20 weeks of gestation. It affects $3-5 \%$ of all pregnancies in the world. It has been reported that the prevalence of preeclampsia has been altered between $1.8 \%$ and $16.7 \%$ in developing countries Women with preeclampsia seem to be at elevated risk for cardiovascular disease.

Objective: This study was done to determine the relation between metabolic syndrome and occurance of pre-eclampsia and to evaluate the use of metabolic score in determining the devolpment and severity of pre-eclampsia. Methods: This is a case-control study includes women attending to obstetric emergency unit in labour. The period of study was about 24 month from January 2017 to December 2018. The cases were divided into two groups: The first group consists of 300 cases with pre-eclampsia which characterized by: Mild pre-eclampsia as blood pressure higher than 140/85 and protein 1+ or greater by drip stik, moderate pre-eclsampsia blood pressure is more than $140 / 85$ and less than $160 / 100$ and protein $1+$ or greater by drip stik. Severe pre-eclampsia (imminant-eclampsia) or blood pressure is higher than 160/100 and protein greater than $3+$ by drip stik. The second group consists of 300 control patients with normal pregnancy.
\end{abstract}


Results: Preeclampsia was a dependent risk factors for metabolic syndrome (adjusted odds ratio $=6.888,95 \% \mathrm{CI}=4.656$ to 10.189 , P-value $<0.0001$ ) . While age category 40-49 years was associated with significantly lower risk for metabolic syndrome as referenced to age category 18-29 years adjusted odds ratio $=0.337,95 \% \mathrm{CI}=0.168$ to 0.677 , $\mathrm{P}$-value $=0.002$ ).

Conclusion: There is a significant relation between the incidence of $\mathrm{PE}$ and presence of metabolic syndrome and the more number of items of metabolic syndrome the higher the risk of occurrence of PE.

Keywords: Metabolic syndrome; pre-eclampsia

\section{INTRODUCTION}

Preeclampsia is a complicated disorder in pregnancy which occurs after 20 weeks of gestation. It affects 3-5\% of all pregnancies in the world It has been reported that the prevalence of preeclampsia has been altered between $1.8 \%$ and $16.7 \%$ in developing countries Women with preeclampsia seem to be at elevated risk for cardiovascular disease (Osungbade and Ige, 2011).

Studies have shown that women with preeclampsia disease show two times risk of cardiac disease, cardiovascular mortality, cerebrovascular and peripheral arterial disease. It has been indicated that many risk factors such as diabetes mellitus, obesity, hypertension and heart disease is often common in preeclampsia and cardiovascular disease patients. There are also another risk factors for preeclampsia include elevated body mass index (BMI) before or during pregnancy, pre-existing diabetes, multiple pregnancies, null parity, autoimmune disease, renal disease and maternal age greater than 40 years old (Duckitt and Harrington, 2005; Miranda et al., 2005). 
The metabolic syndrome is defined as a cluster of metabolic abnormalities such as hypertension, dyslipidaemia, obesity (particularly central obesity), insulin resistance and high fasting plasma glucose. Differences in genetic differences, diet, physical activity, age and sex influence the prevalence of metabolic syndrome and its components pregnancy induced hypertension, respectively. Assessment of the metabolic syndrome may prevent some pregnancy complications (Praramsothy and Knopp, 2008).

It has been reported that dyslipidaemia and insulin resistance are more considerable in preeclampsia women when compared to normal pregnancy, many studies have been shown that there are associations between pre pregnancy obesity chronic hypertension dyslipidemia, and inflammation in early pregnancy and high risk of preterm birth and intrauterine growth restriction. Studies have indicated that people with metabolic syndrome reveal higher frequency of cardiovascular disease and more rate of death from cardiovascular disease (Catov et al., 2008; Galassi et al., 2006).

Patients with high triglyceride show a higher incidence of preeclampsia many studies have indicated high triglycerides, cholesterol, low density lipoprotein (LDL) and reduced high density lipoprotein (HDL) levels in preeclampsia. Another study also revealed that obesity is a risk factor for the progression of PE (Ogura et al., 2002). 
Journal of Environmental Sciences (JES)

Institute of Environmental Studies and Research, Ain Shams University

Zahran, Wafaa et al.

\section{AIM OF THE WORK}

This study was done to study the relation between metabolic syndrome and occurrence of pre-eclampsia and to evaluate the use of metabolic score in determining the development and severity of pre-eclampsia.

\section{PATIENTS AND METHODS}

This is a case-control study includes women attending to obstetric emergency unit in labour in Bolak El Dakror General Hospital. The period of study was about 24 month from January 2017 to December 2018. The studied group was divided into two groups: The first group consists of 300 cases (pregnant women with pre-eclampsia) which characterized by: Mild preeclampsia as blood pressure higher in $140 / 85$ and protein $1+$ or greater by drip stik. Moderate pre-eclsampsia blood pressure is more than 140/85 and less than 160/100 and protein 1+ or greater by drip stik. Severe pre-eclampsia (imminant-eclampsia) or blood pressure is higher than 160/100 and protein greater than $3+$ by drip stik. The second group consists of 300 control pregnant women with normal pregnancy.

\section{For the cases and controls:}

The blood pressure was measured by using a standard mercury manometer with the women in sitting position from their right arms so that, patients with systolic blood pressure equal or more than 140, diastolic blood pressure equal or more than 85 was diagnosed as hypertensive women. 
Body mass index BMI was calculated by weighting the patient and measuring the height, so:

- BMI less than $30 \rightarrow$ not obese

- BMI 30-34 $\rightarrow$ obese

- BMI more than $35 \rightarrow$ morbid obesity

Blood glucose level is measured, so, if more than $100 \mathrm{~g} / \mathrm{ml}$ the woman is diabetic

- High density lipoprotein (HDL) is equal or less than 50.

- Triglycerides (TG) is equal or more than 250.

- Protein in urine was measured by dripstik.

Definition of metabolic syndrome (MS) included the following components:

1- Pre-existing hypertension

2- Diabetes whether gestational or pre-gestational.

3- Body mass index (BMI) equal or more than $30 \mathrm{~kg} / \mathrm{m}^{2}$.

4- High density lipoprotein (HDL) equal or less than $50 \mathrm{mg} / \mathrm{ml}$.

5- Triglycerides (TG) equal or more than $250 \mathrm{mg} / \mathrm{ml}$.

The presence of MS was defined as having three of the five variables assessed using the clinical cut off defined above.

Patients were included in the study according to the following criteria: Gestational age equal or more than 37 weeks. Glucose level equal or more than $100 \mathrm{mg} / \mathrm{ml}, \mathrm{HDL} \leq 50 \mathrm{mg} / \mathrm{ml}, \mathrm{TG} \geq 250$, BMI $\geq 30$, and blood pressure equal or more than $140 / 85$. 


\section{Exclusion criteria}

1- Gestational age less than 37 weeks.

2- Glucose level less than 100, HDL $>50 \mathrm{mg} / \mathrm{ml}, \mathrm{TG} \leq 250 \mathrm{mg} / \mathrm{ml}$.

3- Blood pressure less than 140/85.

4- History of renal, cardiovascular, liver, endocrine disorder or any chronic illness.

\section{Statistical methods:}

Data were analyzed using IBM $\odot$ SPSS $\odot$ Statistics version 23 (IBM $\odot$ Corp., Armonk, NY) and JMP® Version 13.2.1 (SAS@ Institute Inc., Cary, NC). Categorical data were presented as number and percentage and betweengroup differences were compared using Fisher's exact test. Ordinal data were compared using the chi-squared test for trend. Multivariable binary logistic regression analysis was used to examine the relation between preeclampsia and metabolic syndrome with adjustment for the effect of potential confounding factors. Two-sided P-values $<0.05$ were considered statistically significant. 


\section{RESULTS}

Table (1): Demographic characteristics and parity in cases of preeclampsia and controls

\begin{tabular}{|c|c|c|c|c|c|c|c|}
\hline & & \multicolumn{2}{|c|}{ PE $(n=300)$} & \multicolumn{2}{|c|}{ Control $(n=300)$} & \multirow{2}{*}{$\chi^{2}(\mathrm{df}, \mathbf{1})$} & \multirow{2}{*}{ P-value* } \\
\hline \multicolumn{2}{|c|}{ Variable } & $\mathbf{n}$ & $\%$ & $\mathbf{n}$ & $\%$ & & \\
\hline \multirow{3}{*}{ Age } & 18-29 years & 181 & $60.3 \%$ & 147 & $49.0 \%$ & \multirow{3}{*}{1.701} & \multirow{3}{*}{0.192} \\
\hline & 30-39 years & 85 & $28.3 \%$ & 132 & $44.0 \%$ & & \\
\hline & 40-49 years & 34 & $11.3 \%$ & 21 & $7.0 \%$ & & \\
\hline \multirow{4}{*}{$\begin{array}{l}\text { Body mass } \\
\text { index }\end{array}$} & $<30 \mathrm{~kg} / \mathrm{m}^{2}$ & 90 & $30.0 \%$ & 51 & $17.0 \%$ & \multirow{4}{*}{5.289} & \multirow{4}{*}{0.021} \\
\hline & $30-34.9 \mathrm{~kg} / \mathrm{m}^{2}$ & 91 & $30.3 \%$ & 119 & $39.7 \%$ & & \\
\hline & $35-39.9 \mathrm{~kg} / \mathrm{m}^{2}$ & 89 & $29.7 \%$ & 97 & $32.3 \%$ & & \\
\hline & $\geq 40 \mathrm{~kg} / \mathrm{m}^{2}$ & 30 & $10.0 \%$ & 33 & $11.0 \%$ & & \\
\hline \multirow{3}{*}{ Parity } & PO & 157 & $52.3 \%$ & 201 & $67.0 \%$ & \multirow{3}{*}{1.381} & \multirow{3}{*}{0.280} \\
\hline & $P 1-P 4$ & 112 & $37.3 \%$ & 45 & $15.0 \%$ & & \\
\hline & $>P 4$ & 31 & $10.3 \%$ & 54 & $18.0 \%$ & & \\
\hline
\end{tabular}

Data are number (n) and percentage (\%).

$\chi^{2}=$ Chi-squared statistic, $\mathrm{df}=$ degree of freedom.

$*$ Chi-squared test for trend.

Table (1) shows that after adjustment for other factors, age, BMI, parity were independent factors, for pre-eclampsia $\mathrm{P}$ value were $0.192,0.021,0.280$ respectively. 
Table (2): Grading of blood pressure and albuminuria in cases of preeclampsia (PE) and controls

\begin{tabular}{|c|c|c|c|c|c|c|c|}
\hline & \multirow[t]{2}{*}{ Variable } & \multicolumn{2}{|c|}{ PE $(n=300)$} & \multicolumn{2}{|c|}{$\begin{array}{l}\text { Control } \\
(\mathbf{n}=\mathbf{3 0 0})\end{array}$} & \multirow[t]{2}{*}{$\chi^{2}(\mathbf{d f}, 1)$} & \multirow[t]{2}{*}{ P-value* } \\
\hline & & $\mathbf{n}$ & $\%$ & $\mathbf{n}$ & $\%$ & & \\
\hline \multirow{4}{*}{$\begin{array}{l}\text { Blood } \\
\text { pressure }\end{array}$} & $<130 / 90 \mathrm{mmHg}$ & 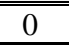 & $0.0 \%$ & 300 & $100.0 \%$ & \multirow{4}{*}{445.767} & \multirow{4}{*}{$<0.001$} \\
\hline & $\begin{array}{l}>130 / 90 \mathrm{mmHg} \text { to } \\
<140 / 100 \mathrm{mmHg}\end{array}$ & 150 & $50.0 \%$ & 0 & $0.0 \%$ & & \\
\hline & $\begin{array}{l}\geq 140 / 100 \mathrm{mmHg} \text { to } \\
<160 / 100 \mathrm{mmHg}\end{array}$ & 120 & $40.0 \%$ & 0 & $0.0 \%$ & & \\
\hline & $>160 / 100 \mathrm{mmHg}$ & 30 & $10.0 \%$ & 0 & $0.0 \%$ & & \\
\hline \multirow{4}{*}{ Albuminuria } & Nil & 0 & $0.0 \%$ & 300 & $100.0 \%$ & \multirow{4}{*}{400.028} & \multirow{4}{*}{$<0.001$} \\
\hline & $1+$ & 179 & $59.7 \%$ & 0 & $0.0 \%$ & & \\
\hline & $2+$ & 61 & $20.3 \%$ & 0 & $0.0 \%$ & & \\
\hline & $3+$ & 60 & $20.0 \%$ & 0 & $0.0 \%$ & & \\
\hline
\end{tabular}

Data are number (n) and percentage (\%).

$\chi^{2}=$ Chi-squared statistic, $\mathrm{df}=$ degree of freedom.

*Chi-squared test for trend.

Table (2) shows that after adjusting for other variables, blood pressure was a dependent factor for pre-eclampsia $\mathrm{X}^{2}(\mathrm{df}, 1)$ 445.767, $\mathrm{P}$ value $<0.001$, albuminuria also was a dependent factor of PE $\mathrm{X}^{2}$ (df,1) 400.028 $\mathrm{P}$ value $<0.001)$. 
Table (3): Results of blood glucose and lipid testing in cases of preeclampsia and controls

\begin{tabular}{|c|c|c|c|c|c|c|c|}
\hline \multirow{2}{*}{\multicolumn{2}{|c|}{$\begin{array}{c}\text { Criteria of metabolic } \\
\text { syndrome }\end{array}$}} & \multicolumn{2}{|c|}{ PE $(n=300)$} & \multicolumn{2}{|c|}{$\begin{array}{l}\text { Control } \\
(\mathrm{n}=300)\end{array}$} & \multirow[t]{2}{*}{$\chi^{2}(\mathrm{df}, 1)$} & \multirow[t]{2}{*}{ P-value* } \\
\hline & & $\mathbf{n}$ & $\%$ & $\mathbf{n}$ & $\%$ & & \\
\hline \multirow{2}{*}{ Blood glucose } & <<100 mg/dl & 205 & $68.3 \%$ & 268 & $89.3 \%$ & \multirow{2}{*}{39.577} & \multirow{2}{*}{$<0.001$} \\
\hline & $\geq 100 \mathrm{mg} / \mathrm{dl}$ & 95 & $31.7 \%$ & 32 & $10.7 \%$ & & \\
\hline \multirow{2}{*}{$\begin{array}{l}\text { High density } \\
\text { lipoprotein }\end{array}$} & $\geq 50 \mathrm{mg} / \mathrm{dl}$ & 178 & $59.3 \%$ & 211 & $70.3 \%$ & \multirow{2}{*}{7.947} & \multirow{2}{*}{0.005} \\
\hline & $<50 \mathrm{mg} / \mathrm{dl}$ & 122 & $40.7 \%$ & 89 & $29.7 \%$ & & \\
\hline \multirow{2}{*}{$\begin{array}{l}\text { Low density } \\
\text { lipoprotein }\end{array}$} & $<250 \mathrm{mg} / \mathrm{dl}$ & 233 & $77.7 \%$ & 283 & $94.3 \%$ & \multirow{2}{*}{34.549} & \multirow{2}{*}{$<0.001$} \\
\hline & $\geq 250 \mathrm{mg} / \mathrm{dl}$ & 67 & $22.3 \%$ & 17 & $5.7 \%$ & & \\
\hline \multirow{2}{*}{ Triglycerides } & $<250 \mathrm{mg} / \mathrm{dl}$ & 109 & $36.3 \%$ & 222 & $74.0 \%$ & \multirow{2}{*}{85.902} & \multirow{2}{*}{$<0.001$} \\
\hline & $\geq 250 \mathrm{mg} / \mathrm{dl}$ & 191 & $63.7 \%$ & 78 & $26.0 \%$ & & \\
\hline
\end{tabular}

Data are number (n) and percentage (\%).

$\chi^{2}=$ Chi-squared statistic, $\mathrm{df}=$ degree of freedom.

*Chi-squared test for trend.

Table (3) shows that there is significant association between the blood glucose level and incidence of pre-eclampsia $X^{2}$ (df,1 39.577, p value < 0.001), good relation between low HDL and incidence of PE $X^{2}$ (df,1) 7.949, p value 0.005 also, high LDL and incidence of pre-eclampsia $X^{2}$ (df,1) $34.549, \mathrm{P}$ value $<0.001$, high TG and incidence of pre-eclampsia $\mathrm{X}^{2}(\mathrm{df}, 1)$ 85.902 , $\mathrm{p}$ value $<0.001)$. 
Table (4): Number of metabolic syndrome criteria in cases of preeclampsia and controls

\begin{tabular}{|c|c|c|c|c|c|c|c|}
\hline \multirow{2}{*}{\multicolumn{2}{|c|}{ Variable }} & \multicolumn{2}{|c|}{ PE $(n=300)$} & \multicolumn{2}{|c|}{$\begin{array}{l}\text { Control } \\
(n=300)\end{array}$} & \multirow[t]{2}{*}{$\chi^{2}(\mathrm{df}, 1)$} & \multirow[t]{2}{*}{ P-value* } \\
\hline & & $\mathbf{n}$ & $\%$ & $\mathrm{n}$ & $\%$ & & \\
\hline \multirow{6}{*}{$\begin{array}{l}\text { Number of } \\
\text { metabolic } \\
\text { syndrome } \\
\text { criteria }\end{array}$} & $\mathrm{Nil}$ & 0 & $0.0 \%$ & 41 & $13.7 \%$ & \multirow{6}{*}{177.266} & \multirow{6}{*}{$<0.001$} \\
\hline & $\begin{array}{l}\text { Single } \\
\text { criterion }\end{array}$ & 64 & $21.3 \%$ & 161 & $53.7 \%$ & & \\
\hline & Two criteria & 36 & $12.0 \%$ & 23 & $7.7 \%$ & & \\
\hline & $\begin{array}{l}\text { Three } \\
\text { criteria }\end{array}$ & 34 & $11.3 \%$ & 59 & $19.7 \%$ & & \\
\hline & Four criteria & 150 & $50.0 \%$ & 16 & $5.3 \%$ & & \\
\hline & Five criteria & 16 & $5.3 \%$ & 0 & $0.0 \%$ & & \\
\hline
\end{tabular}

Data are number (n) and percentage (\%).

$\chi^{2}=$ Chi-squared statistic, $\mathrm{df}=$ degree of freedom.

*Chi-squared test for trend.

Table (4) shows significant association between the number of metabolic syndrome criteria in cases and controls. The more the number of criteria the high percentage of pre-eclampsia

Table (5): Proportion of patients ultimately diagnosed as having metabolic syndrome among cases of preeclampsia and controls

\begin{tabular}{|c|c|c|c|c|c|c|}
\hline & \multirow{2}{*}{ Variable } & \multicolumn{2}{|c|}{ PE $(n=300)$} & \multicolumn{2}{|c|}{$\begin{array}{l}\text { Control } \\
(n=300)\end{array}$} & \multirow{2}{*}{ P-value* } \\
\hline & & $\mathbf{n}$ & $\%$ & $\mathbf{n}$ & $\%$ & \\
\hline \multirow{2}{*}{$\begin{array}{l}\text { Metabolic } \\
\text { syndrome }\end{array}$} & $\begin{array}{l}\text { No metabolic syndrome }(\leq 2 \\
\text { criteria) }\end{array}$ & 100 & $33.3 \%$ & 225 & $75.0 \%$ & \multirow{2}{*}{$<0.001$} \\
\hline & Metabolic syndrome ( $\geq 3$ criteria) & 200 & $66.7 \%$ & 75 & $25.0 \%$ & \\
\hline
\end{tabular}

Data are number (n) and percentage (\%).

*Fisher's exact test. 
Table (5) shows the incidence of metabolic syndrome in pre-eclampsia $(66.7 \%)$ patients and in control $(25 \%) \mathrm{P}$ value $<0.001$.

\section{DISCUSSION}

Recently, the incidence of pre-ecalmpsia has increased, probably in part because of obesity. Similarly, obesity by BMI in the non pregnant state was associated with increased risk of developing pre-eclampsia (Ananth et al., 2013). In this study, we evaluated the association between pre-pregnancy factors and the development of pre-eclampsia, we found that metabolic syndrome in the non-pregnant state has associated with an increased risk. Moreover, the incidence increased when the number of components of metabolic syndrome increased. The interpregnancy metabolic syndrome reportedly also predisposes to recurrent pre-eclampsia, although the time of onset of metabolic syndrome is unknown (Stekkinger et al., 2013). Although the clinical findings of PE are first noted during pregnancy, the under pinnings of the condition may originate prior to pregnancy (Wen et al., 2012).

Cho et al. (2016) evaluate the association between pre-pregnancy factors and development of PE. They found that MS in the pregnant state was associated with an increased risk. Moreover, the incidence of PE rose when the number of components of MS increased. Management strategies for MS including life style intervention, lower the risk of long-term cardiovascular disease (CVD) (Wong, 2005; Deen, 2004). 
Journal of Environmental Sciences (JES)

Institute of Environmental Studies and Research, Ain Shams University

Zahran, Wafaa et al.

Dietary and lifestyle intervention, has been also known to reduce the risk of PE (Allen et al., 2014). In this study, the prevalence of MS was lower than that in previous studies (Park and Kim, 2015). This may attributed to the exclusion of women with hypertension in non pregnant state $n=2.697$. The lower incidence may be also due to the characteristics of the other study population which consisted of a younger age group (Mean age 30.44 3.27 years). Moreover in this study only $36 \%$ of the population had $\geq 1$ cardiovascular risk factor among the component of MS i.e., obesity and BMI and a family history of hypertension. This is lower than the result of another study which reported that $\leq 60 \%$ of reproductive aged women have $\geq 1$ cardiovascular risk factor (Daviglus et al., 2004).

The cause of PE is unknown but previous studies found an association of elevated BMI and PE (Rudra and Williams, 2005). Women with low BMI have lower risk of PE than women at normal or higher BMI (Belghiti et al., 2011).

The mechanism by which obesity increases the incidence of PE could include insulin resistance or inflammation (McDonald et al., 2013). Insulin resistance has been associated with endothelial dysfunction (Valerio et al., 2011), and increased secretion of enothelin 1 a potent vasoconstrictor. In addition, insulin resistance results in reduction of nitric oxide, increasing the risk of hypertension and CVD (Menzies et al., 2007).

Kianpour et al. (2015) in their study found that the mean fasting blood sugar, triglyceride level and HDL level of the participants in weeks 20 and 30 
Journal of Environmental Sciences (JES)

Institute of Environmental Studies and Research, Ain Shams University

Zahran, Wafaa et al.

of pregnancy in women with metabolic syndrome and healthy women they found that fasting blood sugar (FBS) and triglyceride level in the two groups were significantly different $(\mathrm{P}<0.001)$ but the amount of HDL was not significant. The relative frequency of PE in pregnant women with MS and healthy subjects was significantly different $(\mathrm{P}<0.001)$. The frequency of $\mathrm{PE}$ before 30 ws based on Fisher's exact test in women with MS has $8.2 \%$ and in healthy group was $1.2 \%$ after 30 ws of pregnancy based on Chi-square test, the frequency of PE in women of MS was $37.7 \%$ and in healthy group was $10.6 \%$.

The relation between the items of MS and PE was studied. Based on the findings, it was observed that relative frequency of PE in pregnant women with MS and the control group was significantly different $(\mathrm{P}<0.001)$. This agreed with Lorenzo et al. (2003) in their study showed that women with MS compared to the healthy group had significantly more blood disorder $(\mathrm{P}<0.001) 31 \%$ increased pregnancy hypertension, and $46 \% \mathrm{PE}$ in patients with MS.

In the present study $40.7 \%$ of the cases with PE had low HDL $(<50$ $\mathrm{mg} / \mathrm{dl}$ ) while $29.7 \%$ of the control group has low HDL $\mathrm{X}^{2}(\mathrm{df}, 1) 7.947, \mathrm{P}=$ 0.005. This result disagrees with Lorenzo et al. (2003) who said that there is no significant difference between the two groups. Also, in the present study $31.7 \%$ of the cases are with fasting blood glucose more than $100 \mathrm{mg} / \mathrm{dl}$ while $10.7 \%$ of the control group had higher FBG $\left.\mathrm{X}^{2}(\mathrm{df}, 1) 39.577, \mathrm{P}<0.001\right)$. Also 
Journal of Environmental Sciences (JES)

Institute of Environmental Studies and Research, Ain Shams University

Zahran, Wafaa et al.

$63.7 \%$ of the cases with $\mathrm{PE}$ had high $\mathrm{TG} \geq 250 \mathrm{mg} / \mathrm{dl}$ while $26 \%$ of the control had high $\mathrm{TG} \mathrm{X}^{2}(\mathrm{df}, 1)$ 85.902, $\mathrm{P}<0.001$. Also these results agree with Lorenzo et al. (2003).

Regarding the BMI group was found that $70 \%$ of the cases of PE are $\mathrm{BMI} \geq 30 \mathrm{~kg} / \mathrm{m} 2$ while $83 \%$ of the control has BMI $\geq 30 \mathrm{~kg} / \mathrm{m}^{2} \mathrm{X}^{2}(\mathrm{df}, 1) 5.289$ $\mathrm{P}=0.021$. So there is insignificant difference in the 2 groups regarding BMI. This is disagree with Dane et al. (2009) who said that body mass index were significantly difference between the 2 groups of pregnant women with PE and healthy women $(\mathrm{P}<0.01)$. Our study agree with Rubbin Azize et al. (2007) who said that serum TG in women with PE were higher than in control group $(\mathrm{P}<0.001)$. Regarding the level of HDL cholesterol, in our study there was no significant difference between the cases and control group while Rubbin Azize et al. (2007) said that the mean HDL cholesterol in women with PE was lower in control group.

Gratacos et al. (2009) study the levels of TG and LDL in severe PE and control groups, their results showed significant difference in the mean levels of these variables between the two groups $\mathrm{P}<0.001)$. In their study, TG level in the PE group was 198.76 while in control group was 167 and LDL level in PE group was 309 while in control group was 217. These results were consistent with those of our study.

The risk of severe PE increased when BMI is the highest, also, Akhavan et al. (2009) revealed the relationship between hyperlipidemia and severity of PE severe PE showed an elevation of plasma TG, cholesterol and LDL. 
Journal of Environmental Sciences (JES)

Institute of Environmental Studies and Research, Ain Shams University

Zahran, Wafaa et al.

Cholesterol concentration when compared to control group which are in agreement of current study. While Baker et al. (2009) disagreed so that he said that women with the most severe form of PE has TG level similar to normotensive controls

After a systemic evaluation of the results of these studies. It can be found whether these indicators are suitable markers for predicting PE or not. Lorenzo et al. (2003) Rubbin Azize et al. (2007), Gratacose et al. (2009) believe that dyslipidemia associated with PE can occur due to endothelial dysfunction accumulation of cholesterol and TG in patient can even damage the endothelial function. Solomon and Seeley (2011) suggested that insulin resistance might involved in pathogenesis of prepregnancy hypertension. Lei et al. (2016) in their study the mean age of the pregnant women presented in the study was $29.07 \pm 5.04$ years $56.95 \%$ of them were primiparous women.

Stuebe et al. (2012) and Ovesen et al. (2011) said that elevated pre BMI and maternal obesity have been linked to a variety of pregnancy complication such as gestational diabetes mellitus (GDM) and PE. Wiznitzer et al. (2009) proved that lipid levels changed substantially during gestation, and abnormal levels of TG were associated with pregnancy complications. Bartha et al. (2008) found that metabolic syndrome was presented in about one third of women with pregnancy induced hypertension and in $10 \%$ of with late onset gestational diabetes. Chatzi et al. (2009) study showed that women with metabolic syndrome found in early pregnancy were at high risk of GDM (RR 
Journal of Environmental Sciences (JES)

Institute of Environmental Studies and Research, Ain Shams University

Zahran, Wafaa et al.

= 3.17: 95\% CI). Baliutaviciene et al. (2012) Pointed out that metabolic syndrome can be diagnosed not only before or after pregnancy but also during pregnancy.

Salzer et al. (2015) revealed that insulin resistance and hyperinsulinemia may be the basic common ground for MS of pregnancy. Moreover, MS is also associated with endothelial dysfunction oxidative stress, attenuated inflammatory response, maternal ability to adapt to these physiological changes can expose underlying previously silent cardiac pathology which is why some call pregnancy natures stress test. Alberti et al. (2009) suggest that MS is a complex of interrelated risk factors for CVD and diabetes. These factors include hyperglycaemia raised BP elevated TG, low HDL and obesity.

The current study is consistent with Smith et al. (2009), Stekkinger et al. (2009), Lu et al. (2011) they said that the prevelance of MS components in PE women was high in their study subjects. Also our finding are in agreement with the study of Smith et al. (2009) who showed a higher prevalence of metabolic syndrome among women with PE compared to healthy pregnant women. Dane et al. (2009), Mazar et al. (2007) revealed that metabolic score during pregnancy have a role in predicting of PE.

Many studies indicated that overweight cause insulin resistance. Belfort et al. (2005) elevate inflammatory markers and risk of developing CVD. Driul et al. (2008) reported that obese women were time more probably to develop PE. It has also indicated that there is an association between Choi 
Journal of Environmental Sciences (JES)

Institute of Environmental Studies and Research, Ain Shams University

Zahran, Wafaa et al.

intolerance, hypertriglyceridemia and low HDL with the development of PE (Ray et al., 2006).

Rafeeinia et al. (2014) in their study showed that dyslipidemia is an important risk factor for $\mathrm{PE}$ in overweight pregnant women which is in agreement with the present study and the finding of other studies showing that women who develop PE have higher TG, cholesterol and LDL and lower HDL cholesterol concentration than healthy pregnant women.

Several studies have shown the association between pre-pregnancy overweight and metabolic pathways dysregulation during pregnancy (LopezJaramilo, 2009). The serum lipids increased in women with PE.

The pathogenesis of PE may be dependant on lipid synthesis alteration and lipid metabolism abnormality (Baksu et al., 2005). Many studies have been shown the association of high TG and LDL cholesterol with pathogenesis of PE. Some other studies have demonstrated the association between lipid level and severity of PE (Belogolovkin et al., 2007).

\section{CONCLUSION}

There is a significant relation between the incidence of PE and presence of metabolic syndrome and the more number of items of metabolic syndrome the high risk of occurrence of PE. 


\section{REFERENCES}

Akhavan S, Modarres Gilani M, Borna S, Shahghaibi S, Yousefinejad V, Shahsavari S (2009): Maternal plasma lipid concentrations in first trimester of pregnancy and risk of severe preeclapmsia. Pak $\mathbf{J}$ Med Sci; 25(4):563-7.

Alberti K, Eckel RH, Grundy SM, et al. (2009): Harmonizing the metabolic syndrome a joint interim statement of the international diabetes federation task force on epidemiology and prevention; national heart, lung, and blood institute; American heart association; world heart federation; international atherosclerosis society; and international association for the study of obesity. Circulation; 120(16): 1640- 1645.

Allen R, Rogozinska E, Sivarajasingam P, Khan KS, Thangaratinam S (2014): Effect of diet and lifestyle-based metabolic riskmodifying interventions on preeclampsia: a meta-analysis, Acta Obstet. Gynecol. Scand. 93: 973-985.

Ananth CV, Lawrence KM, Cleary K (2013): Pre-eclampsia and cardiovascular disease: More questions than answers? BJOG; 120:920-3.

Baker AM, Klein RL, Moss KL, Haeri S, Boggess K (2009): Maternal serum dyslipidemia occurs early in pregnancy in women with mild but not severe preeclampsia. Am J Obstet Gynecol 201: 293.e1-4.

Baksu B, Baksu A, Davas I, Akyol A, Gülbaba G (2005): Lipoprotein (a) levels in women with pre-eclampsia and in normotensive pregnant women. J. Obstet. Gynaecol. Res; 31:277-282.

Baliutavičienè D, Buinauskienė JB, Petrenko V, Danytė E, Žalinkevičius R (2012): Gestational diabetes, obesity, and metabolic syndrome diagnosed during pregnancy. Metab Syndr Relat Disord; 10(3): 214- 217. 
Bartha JL, González-Bugatto F, Fernández-Macías R, González-González NL, Comino-Delgado R, Hervías-Vivancos B (2008): Metabolic syndrome in normal and complicated pregnancies. Eur J Obstet Gynecol Reprod Biol; 137( 2): 178- 184.

Belfort R, Mandarino L, Kashyap S, Wirfel K, Pratipanawatr T, Berria R, Defronzo R A, Cusi K (2005): Dose-response effect of elevated plasma free fatty acid on insulin signaling. Diabetes; 54(6):16401648.

Belghiti J, Kayem G, Tsatsaris V, Goffinet F, Sibai BM, Haddad B (2011): Benefits and risks of expectant management of severe preeclampsia at less than 26 weeks gestation: the impact of gestational age and severe fetal growth restriction. Am J Obstet Gynecol, 205: 465-466.

Belogolovkin V, Eddleman K A, Malone F D, Sullivan L, Ball R H, Nyberg D A, Comstock C H, Hankins G D, Carter S, Dugoff L, Craigo S D, Timor-Tritsch I E, Carr S R, Wolfe H M, D'Alton M E (2007): The effect of low body mass index on the development of gestational hypertension and preeclampsia. J. Matern. Fetal Neonatal. Med; 20:509-513.

Catov J M, Nohr E A, Olsen J, Ness R B (2008): Chronic hypertension related to risk for preterm and term small for gestational age births. Obstet. Gynecol.; 112:290-296.

Chatzi L, Plana E, Pappas A, et al. (2009): The metabolic syndrome in early pregnancy and risk of gestational diabetes mellitus. Diabetes Metab; 35(6): 490- 494.

Cho GJ, Park JH, Shin SA, Oh MJ, Seo HS (2016): Metabolic syndrome in the non-pregnant state is associated with the development of preeclampsia. International Journal of Cardiology; 203:982-6.

Dane B, Dane C, Kiray M, Koldas M, Cetin A (2009): A new metabolic scoring system for analyzing the risk of hypertensive disorders of pregnancy. Arch. Gynecol. Obstet; 280:921-924. 
Daviglus ML, Stamler J, Pirzada A, Yan LL, Garside DB, Liu K, et al. (2004): Favorable cardiovascular risk profile in young women and long-term risk of cardiovascular and all-cause mortality, JAMA 292: 1588-1592.

Deen D (2004): Metabolic syndrome: time for action, Am. Fam. Physician 69: 2875-2882.

Driul L, Cacciaguerra G, Citossi A, Martina M D, Peressini L, Marchesoni D (2008): Prepregnancy body mass index and adverse pregnancy outcomes. Arch. Gynecol. Obstet; 278(1):23-26.

Duckitt K, Harrington D (2005): Risk factors for pre-eclampsia at antenatal booking: Systematic review of controlled studies. BMJ; 330(7491):565.

Galassi A, Reynolds K, He J (2006): Metabolic syndrome and risk of cardiovascular disease: a meta-analysis. Am. J. Med; 119:812819.

Gratacós E, Casals E, Gómez O, Llurba E, Mercader I, Cararach V, et al. Vol. 280. Austria (W.M): (2009): Diagnostic increased susceptibility to low density lipoprotein Oxidation in women with a history of preeclampsia, university of Graz; pp. 921-6.

Kianpour M, Norozi S, Bahadoran P, Azadbakht L (2015): The relationship between metabolic syndrome criteria and preeclampsia in primigravid women. Iranian journal of Nursing and Midwifery Research; 20(2):263.

Lei Q, Niu J, Lv L, Duan D, Wen J, Lin X, Mai C, Zhou Y (2016): Clustering of metabolic risk factors and adverse pregnancy outcomes: a prospective cohort study. Diabetes/metabolism Research and Reviews; 32(8):835-42.

Lopez-Jaramillo P (2009): Cardiometabolic disease in latin america: The role of fetal programming in response to maternal malnutrition. Rev. Esp. Cardiol; 62(6):670-676. 
Lorenzo C, Okoloise M, Williams K, Stern MP, Haffner SM (2003): San Antonio Heart Study. The metabolic syndrome as predictor of type 2 diabetes: The San Antonio heart study. Diabetes Care; 26:3153-9.

Lu J, Zhao Y Y, Qiao J, Zhang H J, Ge L, Wei Y (2011): A follow-up study of women with a history of severe preeclampsia: relationship between metabolic syndrome and preeclampsia. Chin. Med. J. (Engl);124:775-9.

Mazar R M, Srinivas S K, Sammel M D, Andrela C M, Elovitz MA (2007): Metabolic score as a novel approach to assessing preeclampsia risk. Am. J. Obstet. Gynecol.; 197:411.e1-e5.

McDonald SD, Yusuf S, Walsh MW, Lonn E, Teo K, Anand SS, et al. (2013): Increased cardiovascular risk after pre-eclampsia in women with dysglycaemia. Diabet Med., 30: e1-e7.

Menzies J, Magee LA, Macnab YC, Ansermino JM, Li J, Douglas MJ, et al. (2007): Current CHS and NHBPEP criteria for severe preeclampsia do not uniformly predict adverse maternal or perinatal outcomes. Hypertens Pregnancy, 26: 447-462.

Miranda PJ, DeFronzo RA, Califf RM, Guyton JR (2005): Metabolic syndrome: definition, pathophysiology, and mechanisms. Am. Heart J; 149:3345 .

Ogura K, Miyatake T, Fukui O, Nakamura T, Kameda T, Yoshino G (2002): Low-density lipoprotein particle diameter in normal pregnancy and preeclampsia. J. Atheroscler. Thromb; 9:42-47.

Osungbade KO, Ige OK (2011): Public health perspectives of preeclampsia in developing countries: Implication for health system strengthening. J Pregnancy; 2011:481095. 
Ovesen P, Rasmussen S, Kesmodel U (2011): Effect of prepregnancy maternal overweight and obesity on pregnancy outcome. Obstet Gynecol; 118(2 Pt 1): 305-312.

Paramsothy P, Knopp R H (2008): Metabolic syndrome in women of childbearing age and pregnancy: Recognition and management of dyslipidemia. Metab. Syndr. Relat. Disord; 3:250-258.

Park E, Kim J (2015): Gender- and age-specific prevalence of metabolic syndrome among Korean adults: analysis of the Fifth Korean National Health and Nutrition Examination Survey, J. Cardiovasc. Nurs. 30:256-266.

Rafeeinia A, Tabandeh A, Khajeniazi S, Marjani A (2014): Metabolic syndrome in preeclampsia women in gorgan. The Open Biochemistry Journal; 8:94.

Ray J G, Diamond P, Singh G, Bell C M (2006): Brief overview of maternal triglycerides as a risk factor for pre-eclampsia. BJOG; 113(4):379-386.

Rubbin Azize F, Zhangtm S, Zerugp S (2007): The association between metabolic syndrome and profile lipid in pregnancy 5:356-789.

Rudra CL, Williams MA (2005): BMI as a modifying factor in the relations between age at menarche, menstrual cycle characteristics, and risk of preeclampsia. Gynecol Endocrinol, 21: 200-205.

Salzer L, Tenenbaum-Gavish K, Hod M (2015): Metabolic disorder of pregnancy (understanding pathophysiology of diabetes and preeclamps). Best Pract Res Clin Obstet Gynaecol; 29(3): 328338.

Smith G N, Walker M C, Liu A, Wen S W, Swansburg M, Ramshaw H, White R R, Roddy M, Hladunewich M (2009): Pre-Eclampsia New Emerging Team (PE-NET).A history of preeclampsia identifies women who have underlying cardiovascular risk factors. Am. J. Obstet. Gynecol; 200:58.e1-e8.

Solomon CG, Seely EW (2011): Hypertension in pregnancy. Endocrinol Metab Clin North Am; 40(4): 847- 863. 
Stekkinger E, Scholten R, van der Vlugt MJ, van Dijk AP, Janssen MC, Spaanderman ME (2013): Metabolic syndrome and the risk for recurrent pre-eclampsia: a retrospective cohort study. BJOG 120: 979-986.

Stekkinger E, Zandstra M, Peeters L L, Spaanderman M E (2009): Earlyonset preeclampsia and the prevalence of postpartum metabolic syndrome. Obstet. Gynecol; 114:1076-84.

Stuebe AM, Landon MB, Lai Y, et al. (2012): Maternal BMI, glucose tolerance, and adverse pregnancy outcomes. Am J Obstet Gynecol; 207(1): 62.e1-62.e7.

Valerio EG, Muller AL, Martins-Costa SH, Lopes Ramos JG, Rodini G (2011): Are insulin resistance index, IGF-1 and metabolic syndrome components correlates with severe preeclampsia?. Hypertens Pregnancy, 30: 302-310.

Wen SW, Xie RH, Tan H, Walker MC, Smith GN, Retnakaran R (2012): Preeclampsia and gestational diabetes mellitus: pre-conception origins? Med. Hypotheses 2012; 79:120-125.

Wiznitzer A, Mayer A, Novack V, et al. (2009): Association of lipid levels during gestation with preeclampsia and gestational diabetes mellitus: a population-based study. Am J Obstet Gynecol; 201(5): 482.e1-482.e8.

Wong ND (2005): Intensified screening and treatment of the metabolic syndrome for cardiovascular risk reduction, Prev. Cardiol. 8: 4752 quiz 53-44. 


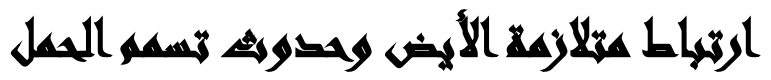 لـى الميدايت}

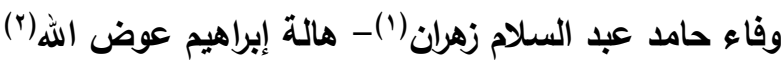

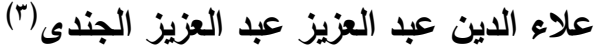

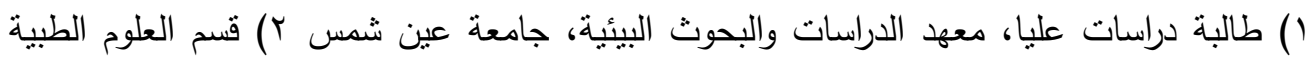

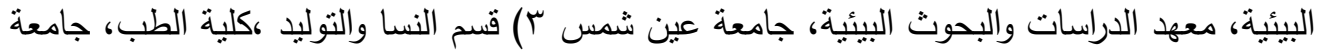
عين شمس لمسئ

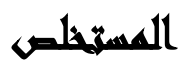

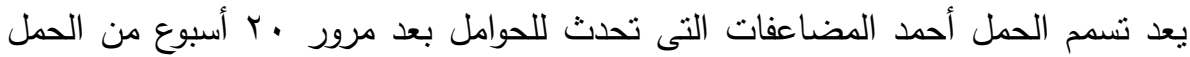

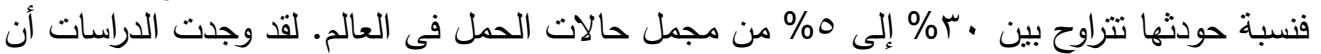

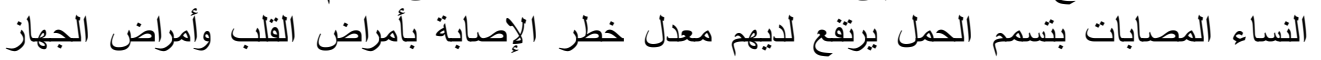

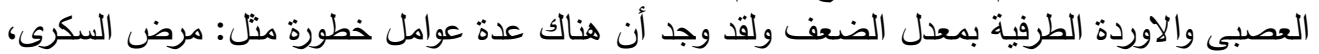

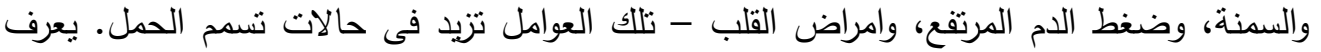

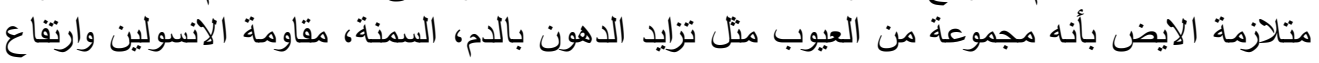

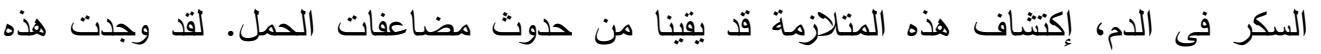

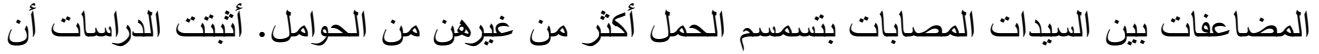

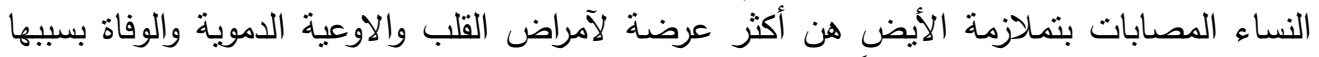

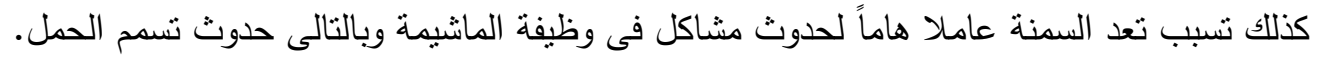

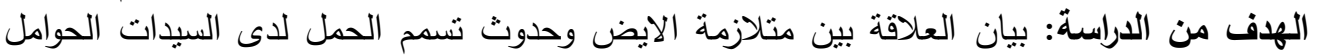

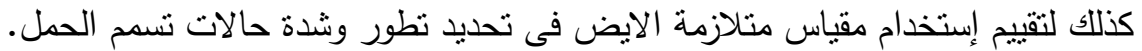

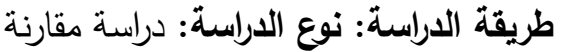

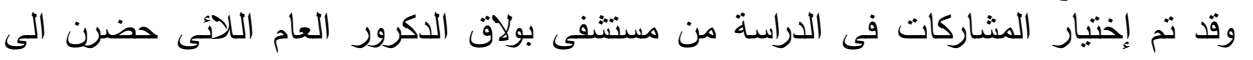

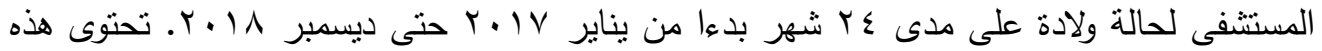

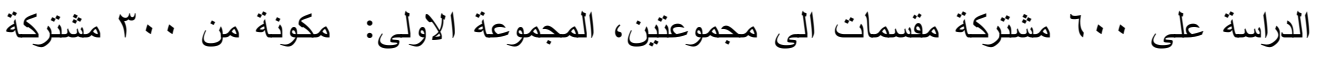

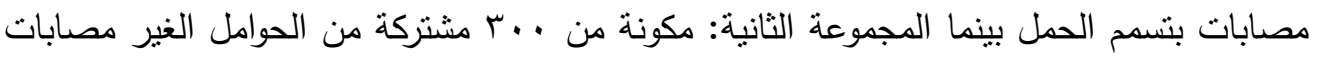

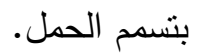


Journal of Environmental Sciences (JES)

Institute of Environmental Studies and Research, Ain Shams University

Zahran, Wafaa et al.

الخلاصة: أظهرت النتائج الاحصائية للاراسة أنه هناك علاقة ذات دلالة إحصائية بين متلازمة

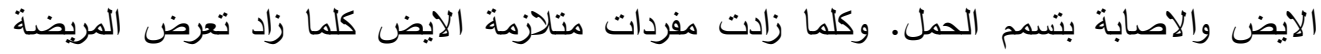

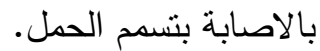
كلمات دالة: متلازمة الايض - تشمم الحمل

Vol.(49); Iss.(12); No.(2); Dec..2020 